\title{
Caring for the Dead and the Living
}

\section{DPs and the Arolsen Archives of Feelings}

\begin{abstract}
Although Displaced Persons (DPs) made crucial contributions to the organization and operation of the International Tracing Service in its early years, their work in the ITS has not been analyzed in any depth. Playing the dual role of archivists who handled the files and subjects whose stories were collected in the files, they were instrumental both in the ITS's mission of tracing the fate of the victims of Nazi persecution and in the creation of a community within the ITS where Displaced Persons could find a safe place of healing. Using archival sources and oral interviews to recover the stories of the DPs in Bad Arolsen not only changes our narrative about Displaced Persons after the Second World War but also reconstructs the ITS as an archive of feeling, in Ann Cvetkovich's terminology. Understanding the importance of their work and continuing DPs' efforts to be responsive to the "pain of others" make possible active, multidirectional memory practices that not only look to the past but also to the politics of the now.
\end{abstract}

\section{Introduction}

Jakob Verbitzki's personnel file in the Arolsen Archives - the new name for the International Tracing Service (ITS) in Bad Arolsen and one of the largest archives of Holocaust documents in the world - contains two certificates of employment from May and August 1949, which he needed in order to apply for a reduced-fare train ticket to visit the grave of his wife in the Ruhr region. ${ }^{1}$ Verbitzki, a Displaced Person (DP) from Ukraine who was employed as a janitor in the International Tracing Service in 1949, was one of the few DPs who had a physical place that could hold the memories of a dead loved one. The fact that he seems to have taken the long trip repeatedly in times when such travel was difficult and expen-

1 The ITS was first set up as a tracing service to help families of victims receive information about the fate of their loved ones and assist Allies in repatriating the millions of Displaced Persons who were stranded in Germany. Its name has recently been changed to Arolsen Archives International Center on Nazi Persecution. For the sake of convenience, I use the name ITS for most of my examples that occurred when the archive was still named ITS in the time between 1948 and 2018.

๑ OpenAccess. (C) 2020 Silke von der Emde, published by De Gruyter. (cc))BY-NC-ND This work is licensed under the Creative Commons Attribution-NonCommercial-NoDerivatives 4.0 License. 
sive testifies to the emotional importance of place for the grieving process. The ITS employees must have understood the heartbreak and pain of mourning because they thought that this detail was important enough to include in Verbitzki's personnel file. ${ }^{2}$ Surprisingly, the ITS at that time not only provided a place of employment for many DPs stranded in Germany but also supported them in dealing with their painful memories and coming to terms with the trauma they had experienced.

Although DPs made crucial contributions to the organization and operation of the ITS in its early years, their work in the ITS has not been analyzed in any depth. In a sense, their narratives have been just as displaced in the archive as the people who helped build it. One reason for this neglect is that the ITS was focused on events before 1945 and not on experiences after the war. Furthermore, the stories of DPs' continuing trauma challenge our familiar post-war narrative of redemption in which the Allies liberated the Nazi concentration camps and the survivors embarked on new lives. ${ }^{3}$ Rather than easy redemption, however, the stories of the DPs tell of long lasting physical and psychological wounds that stubbornly refused to go away. Because emotions have long been defined as private and feminine, the continuing traumatic experiences of the DPs were deemed neither important nor practical enough to be filing priorities in the ITS.

Long considered women's labor, feelings have often been hidden within the archive and thus overlooked by researchers. Yet, traces of affect and empathy in the records of the ITS show that responding to what Susan Sontag has powerfully termed "the pain of others" actually became a modus operandi in the archives. ${ }^{4}$ I argue that focusing on the records of DPs employed in the ITS after the war and reading their records with an eye to the affective content of the documents can reveal how these individuals helped create the International Tracing Service as an archive of feelings in Ann Cvetkovich's sense of the term. ${ }^{5}$ Just as with LBGTQ archives that Cvetkovich analyses, affects are encoded in the ITS documents not only in their content but also in the practices that surround their production and reception. My work with the DP personnel files shows that the presence and work of the DPs in the ITS functioned to keep the affective essence of the millions of documents collected in Arolsen in constant view, bear-

2 ITS Administrative Archives, Personnel File of Jakob Verbitzki, ITS Archive, Arolsen Archives. 3 Compare Ben Shephard: The Long Road Home: The Aftermath of the Second World War, New York: Anchor Books, 2012, and Dan Stone: The Liberation of the Camps: The End of the Holocaust and Its Aftermath, New Haven and London: Yale University Press, 2015.

4 Susan Sontag: Regarding the Pain of Others, New York: Farrar, Straus \& Giroux, 2003.

5 Ann Cvetkovich: An Archive of Feelings: Trauma, Sexuality, and Lesbian Public Cultures, Durham and London: Duke University Press, 2003. 
ing the potential for active, multi-directional memory practices that not only look to the past but also to the politics of the now.

Focusing on and recognizing the value of emotion is a fairly recent development in archival discourse. ${ }^{6}$ In this different kind of archival work, archivists become deeply implicated in the relations and ethics of witnessing because, as feminist cultural theorist Sara Ahmed maintains, it is the relationship of witnessing that gives emotions such as pain a life beyond the fragile, vulnerable borders of an individual body and authenticates its very existence. ${ }^{7}$ In the case of the ITS, the DPs who helped set up the archive and organized its search tools knew firsthand that "archivists are deeply implicated in webs of affective relations" because they were both the archivists who handled the records and the subjects of these records. ${ }^{8}$ In fact, the DPs were ideal participants in this early work because they had the language skills, the understanding of what the victims had gone through, and the motivation to make this archive useful for them and their families. Most importantly, however, they bore the same pain that permeates the records collected in the archive. The archive therefore not only contains facts necessary to document the crimes of the Nazi regime but also contains traces of what the events meant to the people that were affected by them.

Reading the documents with attention to this affective dimension and drawing on feminist and affect theorists such as Marianne Hirsch, Sara Ahmed, and Ann Cvetkovich, I aim to open a space for the consideration of affect, embodiment, privacy, and intimacy as concerns for history. ${ }^{9}$ Such a feminist reading can draw attention to the experiences of marginalized groups such as those of the DPs that might otherwise remain absent from the historical record. It can point out how - because of the presence of the DPs for whom private and public often overlapped in the ITS - relational forms of memorial transmission and practices were written into the structure of the archive. This feminist approach can illuminate not only which stories and images were privileged and which forgotten, but also how those stories were told and how these images were constructed. As Hirsch points out, "in its awareness of power as a central factor in the construction of the archive, [...] feminist analysis can shift the frames of

6 It only started as part of the affective turn in the 1990s. See Marika Cifor: "Affective Relations: Introducing Affect Theory to Archival Discourse”, in Archival Science 16, 2016, 7-31.

7 Sara Ahmed: The Cultural Politics of Emotion, Edinburgh: Edinburgh University Press, 2004, 30.

8 Marika Cifor: "Affective Relations: Introducing Affect Theory to Archival Discourse”, in Archival Science 16, 2016, 7.

9 Marianne Hirsch: The Generation of Postmemory: Writing and Visual Culture After the Holocaust, New York: Columbia University Press, 2012. 
intelligibility so as to allow new experiences to emerge, experiences that have heretofore remained unspoken, or even unthought." ${ }^{0}$ Shifting our attention from the Allied politicians and international players to the DPs busy behind the scenes and deep within the archive itself can give the victims a voice that has up until now been unheard.

This type of feminist analysis can be especially useful in the context of the Holocaust, which has long been regarded as a limit case for memory and memory studies. In fact, it has been somewhat of an orthodoxy among scholars to treat the traumatic experiences of the Shoah as unrepresentable precisely because they reside at the intersection between emotional and social processes, private and public spheres, as well as memory and history. However, rather than focusing on the irrepresentability of traumatic experiences, Ann Cvetkovich insists that we make traumatic memories productive by understanding them as a call to political action. In fact, she maintains that it is vitally important to keep traumatic experiences in view because they can contradict the denial of emotions in atrocities reflected in many of our archives and cultural institutions. ${ }^{11}$

Nevertheless, this affective dimension of documents is often not easily accessible in archives, and the ITS is no exception. Gendered notions of knowledge production in which detachment, objectivity and rationality are valued have often marginalized emotions in archival discourse. Yet, by deploying tools from literary interpretation and cultural studies such as close attention to the language, tone, and context and the use of a broad range of records, including oral history interviews, we can locate some of the affective facets of the documents. ${ }^{12}$ In fact, the contrast between the voice of the DPs in the ITS files and the dehumanizing Nazi files about the same people cannot be missed. This contrast makes a powerful point about the humanity of the DPs and international officers working in the ITS, who in contrast to the Nazis' instrumentalization of human beings as objects and raw material for labor camps allowed for feelings to play a role in important decisions.

Evidence of the affective dimensions of the archive resides in different locations in the ITS. First, we find it directly in the documents of the DPs, not only in

10 Ibid., 18.

11 Cvetkovich: An Archive of Feelings, 2003.

12 Historians such as Dan Stone have begun calling for the use of tools from cultural studies in the historiography of the Holocaust. He argues, "we need to bring the insights of narrativism, with its focus on the text, and rational constructivism, with its focus on the argument and the discursive context, together" in the historiography of the Holocaust. Dan Stone: "Excommunicating the Past Narrativism and Rational Constructivism in the Historiography of the Holocaust”, in Rethinking History, 21, 4, 2017, 549-566, here 554. 
their wartime documents but also in their personnel files from after the war. Second, other types of evidence are also contained in institutional documents, such as official reports and directives but also in letters by and to the personnel manager, the director, and other officials in the institution. Lastly, oral history materials, such as interviews with former employees conducted over the last two years, provide important sources for emotions that are often not directly recorded in institutions like the ITS. Even if locating the emotional essence of the documents is not always easy, rendering it visible can accomplish three important goals: At one level, it complicates our familiar understanding of post-war developments in Germany; at another level, it challenges traditional notions of the archive and the power structures involved in narrating the past; and finally, it makes the affective power of the documents productive for a transformation of collective memory and public culture. In what follows I show that this happened in very small ways in Bad Arolsen itself as well.

\section{Displaced Persons in the ITS}

Before turning to the ITS itself, it is important to understand the difficult situation that DPs faced after the liberation of the camps by the Allies. Not only did the Allies have distinct attitudes towards different victim groups from the beginning, but their policies were also shaped by the geopolitics of the Cold War, the debates over the future of Europe, and the unfolding events in the Middle East. Ben Shephard points out that the term "displaced persons" was created by the Allies before the war had ended in order to deal with the humanitarian crisis they foresaw. It encompassed not only Jewish and non-Jewish survivors of concentration camps but also a large number of "displaced persons" mostly from Eastern Europe who had been forced to work as slave laborers in the German war economy. All of these people had diverse and complicated wartime histories for which, as Shephard says, “modern terms, such as 'victims' and 'perpetrators' do scant justice."13 Often lacking families in the wake of the Holocaust, the DPs had to struggle with intense loneliness, and they were often unwelcome in their hometowns where they were treated as traitors or collaborators. With more than 20 million people on the move competing for scarce resources, the fight for survival was difficult. ${ }^{14}$ Even if the individuals succeeded in finding shelter in the

13 Shephard: The Long Road Home, 5.

14 In addition to the DPs, there were also other groups, including German refugees and expellees crowding into what remained of the former Reich. 
DP camps the Allies set up, they had to fight to avoid being forcibly repatriated and be allowed to emigrate to places that offered them a chance at a new beginning. Many of the DPs were stateless without the protection of a passport and a nationality that would give them basic civil rights. Moreover, German women, such as Johanna Kopaniak, the long-serving personnel manager at the ITS, lost their German citizenship when they married a Heimatlosen Ausländer (stateless foreigner), a fate that also befell the children of these marriages.

In Arolsen, the small town in Northern Hesse where the ITS was finally set up, the situation was not much better. Although small and somewhat remote, Arolsen was chosen because it was very close to the intersection of three occupational zones, had large intact buildings, a fairly developed infrastructure (ironically because it had been the SS command post for the Fulda-Werra region with an SS officer academy and sub-camp of Buchenwald under the leadership of Higher SS and Police Leader Prince Josias of Waldeck and Pyrmont), and had been spared Allied bombardment. ${ }^{15}$ However, because of this problematic history, the same painful interactions between Germans and DPs that took place in other parts of Germany also occurred in Arolsen to an even greater degree. On the one hand, Arolsen civilians were drawn to the ITS and the DP camps as a place of trade and employment. On the other hand, many locals were upset that in contrast to the German refugees, the foreign DPs had Allied protection, were better fed, were placed in confiscated houses, and were able to use their situation as victims to their advantage. ${ }^{16}$ Early on, the Arolsers tried their best to get rid of the ITS, but when the tracing service grew into one of the most important employers in the town, they changed their mind and tried their best to keep the archive in Arolsen in the midst of Allied debates about moving it to a bigger city and less remote region. However, even when the ITS had moved to a beautiful new building constructed with Allied funds, empathy with the victims and painful processes of mourning were not readily encouraged in Arolsen

15 For more on Arolsen's past, see Gerhard Menk: Waldeck im Dritten Reich: Voraussetzungen und Wirken des Nationalsozialismus im hessischen Norden, Korbach: Archiv der Kreisstadt Korbach, 2010; Michael Winkelmann: "Auf einmal sind sie weggemacht”: Lebensbilder Arolser Juden im 20. Jahrhundert. Eine Dokumentation, Kassel: Jenior und Pressler, 1992 [University Library Kassel, 2008], Anke Schmeling: Josias Erbprinz zu Waldeck und Pyrmont: Der politische Weg eines hohen SS-Führers, Kassel: Jenior und Pressler, 1993 [University Library Kassel, 2008], Bernd Joachim Zimmer: Deckname Arthur. Das KZ-Außenkommando in der SS- Führerschule Arolsen, Kassel: Jenior und Pressler, 1994 [University Library Kassel, 2008], and my own article: "Women in the Archive: Locating the International Tracing Service in German Memory Work”, in Seminar: A Journal of Germanic Studies, 53/3, 2017, 202-218.

16 Compare Dan Stone's analysis of the DP situation in Germany in The Liberation of the Camps, 24. 
- or in post-war Germany, for that matter. For years after the end of the war, the persistence of Nazi ideas and values made it very hard for the DPs to integrate into the life of the town. Newspaper reports documented both the citizens' resentment of the occupation of some of their houses by the DPs, and the constant complaint that German refugees from the East were not supported by the Allies in the same way as DPs. The self-pity and lack of perspective and empathy in early reports during this time are hard to stomach when we read them today. It is no wonder that often the trauma of the DPs did not end with liberation but instead became a systemic and everyday experience in Arolsen and in all of post-war Germany, which was not only unwilling to mourn but also seemed unable to empathize with the survivors and DPs towards whom the Nazis had committed unimaginable crimes.

\section{The Documents' Affective Dimension}

While the DPs were clearly marginalized in the town of Arolsen, they found a much friendlier atmosphere in the ITS, a place that not only gave them employment but also a new community with people who had similar experiences. Nevertheless, their voices have largely not been heard and their stories not told. From postmodern and other archivist thinkers we know that accepted institutionalized appraisal frameworks too often (re)enforce the interests of dominant power structures, and exclude the experiences, values, and desires of marginalized individuals and communities from the archival record. This was certainly true for the DPs in Arolsen. Fortunately, however, we can find some of their voices in the affective layer that is hidden in the ITS archive. Aside from reevaluating the important work that the DPs did in the International Tracing Service and doing emotional justice to their efforts and experiences, reading these records for their affective value also accomplishes a greater political goal in recognizing the implication and ethics of archives as agents of witnessing. In the best case, our work as researchers can contribute to what Hirsch calls the labor of the generation of postmemory. ${ }^{17}$

17 Hirsch defines postmemory as "the relationship that the 'generation after' bears to the personal, collective, and cultural trauma of those who came before - to experiences they 'remember' only by means of the stories, images, and behaviors among which they grew up". She distinguishes between "familial" and "affiliative" postmemory and shows how the transmission of traumatic experiences occurs not only within families but also across a much wider social field. See Marianne Hirsch: The Generation of Postmemory, 5. 
The artefacts in the ITS that have the most affective power are the collection of personal effects (belongings taken from prisoners when they arrived in concentration camps), such as watches, letters, personal pictures and wedding bands: all the things that people deemed important enough to take with them on their deportation journey to the camps. ${ }^{18}$ The emotional value of these objects, which the ITS is still trying to return to family members today, is obvious. It is perhaps somewhat surprising then, that even the personnel files of the DPs employed at the ITS also contain many emotional documents and constitute an archive of feelings in their own right. In addition to rather typical and mundane documents such as job applications, dates of employments, promotions, insurance notifications, etc. found in other personnel files, they include very personal records, such as a list of belongings saved from a room after the DP camp in the barracks had to be vacated, letters from Frau Kopaniak, the administrative director, to the relatives of an elderly employee who needed help, and even a whole correspondence about funeral arrangements for one DP employee, complete with a description of the flower arrangements and a list of mourners. The abundance of ephemerals and non-traditional documents in the personnel files of the ITS show how the DPs and others who worked in the ITS placed a certain value on records and items that carry feelings and emotional reactions. In contrast to the somewhat hostile environment in Arolsen, the ITS seems to have been a place where emotions were acknowledged and taken into consideration.

Two 1957 postcards from Eugen Alakosow's personnel file are a good case in point. ${ }^{19}$ Alakosow, a stateless DP and former chemist from Mariupol, Ukraine was one of the very first employees at the ITS (when it was still run by UNRRA as the Central Tracing Bureau, the CTB). From October 1945 until his emigration to the US in 1957 he worked as a case reviewer. Although he did decide to leave the ITS in order to start a new life in the US, the decision must have been a difficult one for he found it necessary to write one of his last goodbyes, shortly before he boarded the ocean liner, to his colleagues in the ITS. The first postcard that he wrote from Bremen shows an impressive ship on the front and hints at the emotional turmoil that goes along with a decision to leave everyone and everything behind to try for a new start in a foreign country. Worried that he was unable to say goodbye to all of his colleagues before he had to leave, he wanted to make sure that the director conveyed his regret to the ITS community he left behind. The other postcard, this one with a skyline of Boston on the front, was

18 A description of the Arolsen Archives' collection of personal effects has been digitized and can be accessed at https://digitalcollections.its-arolsen.org/010209. Last accessed: 3.7.2019.

19 ITS Administrative Archives, Personnel File of Eugen Alakosow, ITS Archive, Arolsen Archives. 
sent shortly after he had arrived in the US and is addressed to personnel manager Johanna Kopaniak. Aside from a request for a piece of documentation, the card again contains greetings to his colleagues and the promise to keep in touch even across the ocean. After 12 years at the ITS, Eugen Alakosow sent his last communication from his old life in Europe and his first one from his new home in the United States to the ITS, the place that had made it possible for him to be part of a new kind of community in which almost everyone was struggling with the same aftermath of displacement and trauma. The human bond between Alakosow and other ITS employees - apparent in the few sentences contained in these postcards and in the fact that the personnel manager cherished them enough to file them - shows the ITS as much more than just a workplace and archive.

Other documents in the personnel files - institutional by nature - also reveal a community that valued the emotional lives of its employees. Even a simple request of incarceration confirmation for restitution claims, like the one written by Witold Malkowski in 1989, reveals a whole narrative about the person who wrote it. The type of language used in the letter, his tone, the metaphors, and the style together with side notes and comments in the margins carry as much meaning as the facts that are conveyed. The impeccably polite letter that begins with a misspelled "very honored ladies and gentlemen" and goes on with a mix of German, Polish and English and often phonetic spelling of German words with a Polish accent (for example "chaben" instead of "haben") includes a ten dollar bill for shipping and a request to send greetings to a "Herrn G." and his old colleagues at the ITS. ${ }^{20}$ As much as the letter shows Malkowski's continued attachment to the ITS after he left Germany 38 years earlier, it also demonstrates the connection and responsibility that his ITS colleagues still felt toward him, as witnessed by a hand-written note from one of the employees at the ITS ensuring him that greetings were in fact relayed. Furthermore, in the answer letter, the writer does not forget to mention that Herr G. has retired but is still in contact

20 Wording of the original letter: "Sehr geährte Damen und Herrn! Ich möchte sie bitten mier zu senden ein neues Zeugnis und eine Arbeitsbescheinigung wie lange ich bei der Internationalen Suchdienst Stelle gearbeitet chabe, ich brauche einige kopien unterlagen vür den Deutschen Konsulat chier in Buffalo. [...] ich wurde mit andern Polnischen Kamaraden am einen Sontag aus der Kirche von der Deutschen Gestapo rausgeschelt worden, ich wurde unschildigt vür 8 Jahre Zuchthaus verurtelt worden, ich wurde gezwungen mit bedrohung den Haft Protokol zu unterschreiben, das chaben die Gestapo mit allen Polischen Statsbürger getan, und dan wurde ich mit andere Polische bürger nach West Deutschland verschlept worden in einen Lager unterbrcht, das wahr im Morhgebit in Papenburg Emsland an der Holendische Grenze, dort chagen wier Torf gestochen, [...] “ in: ITS Administrative Archives, Personnel File of Witold Malkowski, ITS Archive, Arolsen Archives. 
with his colleagues and that they conveyed Malkowski's greetings to him. Reading this simple letter, we can begin to sense what the ITS meant to Witold Malkowski and how he never forgot the ITS contacts that helped him survive the aftermath of the war. In fact, reading his Care and Maintenance (CM/1) file, we know how hard Malkowski fought to be able to emigrate despite the fact that he was sick. Even with parts of the form illegible, we still learn:

Subject person has been twice hospitalized in Merxhausen. He has a wife and child. Wants to emigrate but has not [been able] to apply for any scheme [?] because of poor health. He has been in Oranienburg and Buchenwald. His wife is healthy, but he himself is under control. Lungs already verheilt [instead of healed].

Malkowski had been arrested in Poland for theft and sentenced to six years slave labor in the moor in Emsland and a warplane factory in Northern Germany followed by a few years in different DP camps before he came to Arolsen in 1949. The ITS seems to have been a safe haven for him because of the way the administration took care of him. We can see evidence of this from a note in his personnel file with a directive to prolong his lunch break for half an hour for him to go home for a good meal to help cure his tuberculosis. The deep humanity that was at work in the ITS on the part of the DPs when they tried to help other victims and on the part of the director, personnel manager and supervisors in the ITS shines through in the details of this astonishing collection of documents.

\section{Emotional Labor and Community in the ITS}

We find affect not only in the records themselves but also in how the records were used and what kind of meaning they had for the people who worked in the archive. There are of course heroic stories in the archive that we know from books and films, such as that of Marian Ciepielowski, one of the prisoners who risked his life to sabotage the cruel medical experiments in Buchenwald. ${ }^{21}$ But even documents of a quieter heroism have immense affective power. An example is the struggle of two sisters who fought for their sick mother to be ap-

21 For more on Ciepielowski's background as part of the prisoner team that sabotaged the medical experiments in Block 34 in Buchenwald, see my article: "Recovering a Displaced Archive: DP Employees of the ITS in Arolsen”, in Christian Höschler and Isabel Panek (eds.): Two Kinds of Searches. Findings on Displaced Persons in Arolsen after 1945, Bad Arolsen: Arolsen Archives, 2019; and Arthur Allen: Fantastic Laboratory of Dr. Weigl: How Two Brave Scientists Battled Typhus and Sabotaged the Nazis, New York: WW Norton \& Company, 2014. 
proved for emigration, helped by the director and personnel manager in the ITS who wrote them glowing work recommendations. In addition, the many cases of people who seem to have suffered from post-traumatic stress disorder (PTSD) are heart-breaking, and the examples of the many employees who tried to help these people are even more touching. Against the backdrop of continued trauma, the ITS became an institution that not only documented the history of persecution and helped find lost relatives and family members, but also provided a support system and even a substitute family for many DPs in Arolsen. ${ }^{22}$

The extent to which feelings were taken into consideration in the daily operations of the ITS is also revealed in a 1967 letter to the director Albert de Cocatrix from Gerda Koschuschko, the wife of a long-time employee who was supposed to be laid off because of new retirement laws. The impeccably polite, yet slightly clumsy and very emotional letter displays the woman's deep trust in the leadership of the ITS, who, as she writes, supplied the DPs with new "courage to go on living" [Lebensmut], by giving them work and a new noble direction after the war. She writes the letter out of fear for her husband's physical and emotional health because, as she writes apologetically, "he is very sensitive, it's his mentality." 23 The fact that she feels obliged to apologize for the "heightened sensitivity" of her husband and at the same time trusts that the director will not hold this "weakness" against him indicates that her husband's nervousness, depression, and other PTSD symptoms were not unusual in the ITS. In fact, the personnel files of the DPs who worked in the ITS contain a large number of documents that seem to point to the aftereffects of traumatization and signs of PTSD. While psychological problems are not surprising in employees who are survivors of concentration camps, forced labor and displacement, it is surprising how patiently the administration and fellow DPs seem to have reacted to people who had even major behavioral and emotional problems. Rather than giving in to the discourse dominated by medical and pathologizing approaches, the leadership of the ITS together with the DP employees seem to have tried to find other more humanizing solutions.

A good example is the case of Maria Sawczenko, an apparently illiterate DP from the Ukraine who worked in the ITS as part of the cleaning staff. Having been deported from her place of work in the Ukraine to do slave labor in Germany, she seemed to have never gotten over the abuse she suffered from the Nazis. Although her file lists education as none and specifies that she speaks Ukrainian

22 For more on the DP employees creating familial or family-like structures in the ITS, see my article "Recovering a Displaced Archive".

23 Gerda Koschuschko, letter to Albert de Cocatrix, 5. 2.1967, in: ITS Administrative Archives, Personnel File of Peter Koschuschko, ITS Archive, Arolsen Archives. 
and only a little bit of German, she remained employed in the ITS until at least 1972 despite accumulating problems. From 1962 on her file is filled with serious accident reports that mostly seem to document injuries from falls. But there are also numerous complaints against her for being aggressive and even attacking other people. When she is finally sued for her aggressive behavior by an elderly couple in 1977, it is Frau Kopaniak, the personnel manager, who helps her write a response to the lawyer which explains that Sawchenko does not speak much German and did not intend to insult the couple. ${ }^{24}$ Instead, she felt persecuted by them. Unfortunately, we do not know what happened to the lawsuit and to Maria Sawchenko. However, the fact that she went to Frau Kopaniak for help, even after she seemingly no longer worked at the ITS, indicates that the ITS became a haven for its employees, even ones who were not always easy colleagues. In stark contrast to the Nazis' treatment of people in forced labor settings and concentration camps where only their work performance was able to prolong their life, the ITS seems to be focused on taking care of members of its community even after their employment had already ended.

Sophie Bernau is another example of an individual that the administration seems to have helped patiently by trying to shift her to other positions after she had many quarrels with colleagues over small details such as whether windows needed to be opened during breaks. Her personnel file contains a handwritten letter to Frau Kopaniak in which she vents about her problems, complains about being sick, and tells Frau Kopaniak who to contact after her death. She even specifies who should get her belongings, specifically a cherished radio, which she wants her granddaughter to have. ${ }^{25}$ The style of the letter indicates that Bernau had some sort of emotional disturbance. Despite having been reprimanded, she still trusts the administration enough to write such a personal letter, and the administration seems to have tried its best to figure out solutions for traumatized employees like her. Clearly, many people in leadership positions in the ITS insisted on the power of a community of people who were practiced in acknowledging pain and dealing with it patiently.

24 ITS Administrative Archives, Personnel File of Maria Sawczenko, ITS Archive, Arolsen Archives.

25 ITS Administrative Archives, Personnel File of Sophie Bernau, ITS Archive, Arolsen Archives. 


\section{Women's Work and the Construction of an Archive of Feelings}

These types of responses from the personnel manager and the director show that the institution had to be committed at some level to the affective dimension in which emotional engagement and empathy were encouraged. While both men and women performed this emotional labor within the institution of the ITS, women did assume a leadership role in this regard. One of the key figures in this context was Johanna Kopaniak, the personnel manager in the ITS who came to Arolsen as a young woman in January 1946 in order to find work. As one of the first German employees in the ITS, she worked there for almost 50 years until she stepped down in 1984. In the ITS, she met her husband Alexander Kopaniak, a stateless DP who had spent more than five years in POW camps in Germany. Although she lost her own German citizenship when she married him and had a very difficult position in Arolsen as a young working woman with three little children and a "foreigner" husband who continued to suffer from his war wounds and what was probably a mild case of PTSD, she never ceased in her empathy and support of her colleagues in the ITS. The files reveal how well she worked with some of the more successful British, American and Swiss directors of the ITS and how much they trusted the young personnel manager in her decisions about how best to assist different people and mediate conflicts.

Fortunately, the ITS had one director, Albert de Cocatrix, first Deputy director (from 1955 on) and then director from 1970 to 77, who explicitly valued this emotional labor and was committed to creating community both within the ITS and between the ITS and the town of Arolsen. It is no surprise that Johanna Kopaniak found him to be one of the best directors the ITS ever had, an evaluation that scholars such as Isabel Panek and others share. ${ }^{26}$ Historians point to the extraordinary period of openness and accessibility that he initiated, and Johanna Kopaniak reinforced this evaluation by emphasizing his personal outreach to people inside and outside the ITS. In fact, under his directorship the archive invited researchers from the outside into the archive and launched several internal research projects, such as research on human experiments, death marches, and, in 1976, the Nazi persecution of homosexuals. De Cocatrix transformed the ITS into an access point for the relevant authorities and supported memory projects of all kinds at a time when memory and responsibility for

26 See the chapter by Henning Borggräfe and Isabel Panek in this volume. 
the past was only beginning to be acknowledged in Germany at large. ${ }^{27}$ According to Johanna Kopaniak, he knew the names of all employees, their spouses and their children, encouraged employees to bring their children into the archive for celebrations and summer job opportunities, and asked about family members who were sick or had other problems. He seems to have been one of the rare but influential men who acknowledged the importance of affect and emotions in making the ITS into an archive that truly advocated for both the dead and the living. ${ }^{28}$

The affective power of the documents of the ITS had the most immediate influence on the people who came in direct contact with the archive, such as the DPs and the international employees who worked there. But this affective power also spilled over to local Germans, especially the young women from Arolsen and the surrounding area who began to be hired when more and more DPs emigrated and the ITS became busier. Most of these affective encounters are not in the archival record in the ITS and need to be accessed instead through oral history interviews. ${ }^{29}$ These oral history interviews not only further demonstrate the emotional dimension that made the ITS into the institution it is today, but also do justice to the heritage of the DPs who trained the young German employees. In the stories they tell about their work and the work climate in the ITS, we can trace the emotional connection they had not only to their colleagues but also to the stories contained in the documents themselves. For example, 80-year old Hanna Koeltz spoke about her job as a typist in the ITS as one of the best jobs she ever had, not just because of the good salary and work conditions, but also because of the solidarity among the employees. The work that these women had to do was actually surprisingly stressful because copying over files meant that, as she explained, "one was not allowed to make any, not even the tiniest mistake." Mistakes would inadvertently lead to a visit to the supervisor's office who had to invalidate the mistaken document and authorize a

27 Henning Borggräfe and Hanne Leßau maintain that in the 1970s and under the leadership of de Cocatrix, the ITS became a pioneer for a confrontation with and examination of NS crimes for a second time in its history. Compare their article: "Die Wahrnehmung der NS-Verbrechen und der Umgang mit den NS-Verfolgten im International Tracing Service”, in Henning Borggräfe, Hanne Leßau, and Harald Schmidt (eds.): Fundstücke: Die Wahrnehmung der NS-Verbrechen und ihrer Opfer im Wandel, Göttingen: Wallstein, 2015, 23-44, here 44.

28 Borggräfe and Panek emphasize de Cocatrix's advocacy for the victims and survivors. See their chapter in this volume.

29 For this project I conducted interviews with several former employees and other witnesses who lived through the early years of the ITS. Unfortunately, many of these witnesses will not be with us for much longer and I recommend that such interviews be conducted and added to the archive. 
new attempt..$^{30}$ However, the way that all the women working in the office supported one another, together with their belief and understanding that what they did was important work, alleviated the stress and made them want to stay at the ITS.

Yet it was not only the connection to colleagues that had affective power. The documents themselves touched these women in profound ways and helped them open up to the victims whose stories the Arolser seemed to want to repress. Hanna Koeltz reported that, "when we had time to read and understand what we copied we couldn't help but cry." She and other German women like her were not able to ignore the voices of the victims and instead were deeply touched by them. Even women who began working in later decades were similarly affected. Margret Schlenke, who began working in the ITS in 1970 and was trained by Vilma Anderson, a DP and former slave laborer from Latvia, and who became head of the children's search division, is another good example of the passion and the sense of community that people felt in the ITS. ${ }^{31}$ In an interview from the fall of 2018, Schlenke spoke of the way that the tracing work did not just end when people left the archive at the end of the day, but kept them emotionally engaged at home and in their daily lives.

There are countless examples of people who witness how the work in the ITS effected people emotionally. ${ }^{32}$ One person I interviewed (name withheld) is the wife of a former employee who was asked to consult for the ITS even after he retired. Her testimony is a good example of how difficult this emotional labor could sometimes be. Herself expelled from the Sudeten area after the war, she felt ambivalent about the ITS. Like Gerda Koschuschko, who was worried about the emotional consternation of her husband, this woman also worried about her husband's health when she saw how deeply the victims' stories touched him. She told me that she wished that her husband could have enjoyed his retirement without continuing to be exposed to these emotional burdens again and again. Clearly, the women and men who performed this emotional labor carried these new experiences outside of their place of work to the people of Arolsen, which could be a painful labor. However, very slowly they were able to contribute to a change of public opinion among the Arolser who, as a group, resisted confronting the past for a long time.

30 Personal Interview, 19.7.2015.

31 For a more detailed discussion of Schlenke's role in the ITS see my article "Recovering a Displaced Archive".

32 Personal Interview, 12.10.2018. 


\section{The Labor of Mourning and the Future of Memory in the Arolsen Archives}

The difficult task of acknowledging painful emotions that accompany trauma and guilt seemed in some regards to have been passed on to the second generation. Having grown up in Arolsen in the 1970s, I and most of my peers had little knowledge of what the ITS did, and we were almost completely ignorant about the important documents that were housed there. I overlapped with the Kopaniaks' youngest son Thomas in high school for a year or so and had no idea that he was the son of a DP. Only after I recently told him about my work in the ITS and my interest in the stories of the DPs who worked there did we begin to talk about his and his family's experiences in Bad Arolsen. Obviously one of the reasons for the ignorance of the younger generation was that, except for the period of openness under director de Cocatrix in the 1970s, the archive was closed to the public (and historians) until 2007. But it was also the case that the emotionality of the documents in the ITS and the difficult situation and status of the people who worked there deterred people from fully acknowledging the archive's mission and purpose. A general social intolerance toward a display of emotions and a suspicion toward the feelings of mourning and regret that must have haunted DPs and Germans alike in Arolsen and made it hard for the survivors and even their children to open up about their personal situation. Only by talking about my own interest in the DP narrative did space open up to acknowledge the emotional burdens that followed the DPs into the next generation.

This work of mourning and opening up to the pain of others is still ongoing in the ITS in Arolsen as well. Just as in Verbitzki's case, the labor of mourning is one that needs to be brought back into German communities. By helping Joseph Verbitzki go and visit the grave of his wife, the ITS not only acknowledged his personal pain but also brought him back into a community in which his emotions were respected and his pain was acknowledged. This kind of emotional acknowledgement not only made a big difference to the survivors, helping them cope with the ongoing trauma and sense of displacement, but it also changed the archive itself. The ITS developed from what the Allies and international politicians had planned as a place where facts and knowledge would be stored, into an archive where layers of emotions are also preserved in less obvious but still accessible ways for our own task of restoring the humanity of the victims and making their voices heard. In this way, the affective layers that run through the archive call us as members of the second and third generation to continue the DPs' memory work. 
The ITS has seen countless changes and transformations over the course of its history. For a long period of time it was a male-dominated, unapproachable and sealed-off organization. This is especially true of the 1980s after de Cocatrix left Arolsen until the opening of the archive in $2007 .{ }^{33}$ Yet, the spirit of openness and outreach that characterized the period under de Cocatrix and Kopaniak in the 1970s and the female directorships starting with Rebecca Boehling in 2013 and continuing with Floriane Azoulay until today needs to be made central going forward. The recent name change of the archive to Arolsen Archives: International Center on Nazi Persecution is an encouraging reflection of this new sensibility. In fact, the announcement of the name change on the ITS website for April 2019 speaks to the Arolsen Archives' important new goal of reaching out to the younger generation in order to "provide opportunities for people to engage with their hearts and minds" (“Angebote schaffen, die Herz und Kopf erreichen”) [author's translation]. ${ }^{34}$ My own research into the narratives of the DPs and their important emotional labor in the archive is meant as a contribution to this task.

The personnel files together with other documents provide a fascinating glimpse into the lives of DPs after liberation. They complement as well as complicate what Dan Stone termed the "standard template of liberation" after the Second World War and what Werner Sollors refers to as a legendary story of success of bringing a country ruled by a ruthless dictatorship back into the fold of democracy through nation building. ${ }^{35}$ While the documents show the difficult and painful emotional labor that the DPs did every day in the archive and in the town Arolsen, they also reveal the remarkable degree of sympathy and genuine care for the victims of Nazi persecution, both dead and living, within the ITS. The tracing service emerges as a community of people who created the conditions for their own recovery and healing by keeping the affective essence of the documents in constant view. Their work included not only tracing people's relatives and helping them gain approval for restitution claims, but also helping people reconstruct and reclaim their own identities. Hardly anyone working in the ITS at that time was unaffected by the documents they handled and organized.

33 Johanna Kopaniak tellingly resigned in 1983 after the new director Philipp Züger slowly revealed his strategy of systematically closing off the archive to the public and actively obstructing research. Although it was only three years before her official retirement age, Kopaniak was unable and unwilling to watch Züger destroy the culture of openness and transparency that she and de Cocatrix had built.

34 Website of the Arolsen Archives, News: https://arolsen-archives.org/news/its-wird-arolsenarchives/. Last accessed: 21.8.2019.

35 Compare Dan Stone: The Liberation of the Camps; and Werner Sollors: The Temptation of Despair: Tales of the 1940s, Cambridge, MA: Harvard University Press, 2014. 
The DPs, together with a surprisingly high number of women in leadership positions, shifted the emphasis away from disaffected knowledge and facts to an important acknowledgement of pain and mourning. Behind the scenes and almost unnoticed in the context of the turbulent cold war politics, the DPs turned the archive into a place where traditional divisions of affect and knowledge, private and public, margin and center, and power and powerlessness were challenged. By opening themselves up to pain and by allowing affect to play a role in their interactions with the documents and with one another, the employees of the archive constructed the ITS as an archive of feeling with profoundly affective power. Putting these emotions in the foreground continues to offer not only opportunities for recovery but also for affecting real social change. The Arolsen Archives have the potential to continue the work that the DPs began and contribute to memory practices that do emotional justice to those who have been overlooked and open people's minds to a broader repertoire for the expression of emotion. 